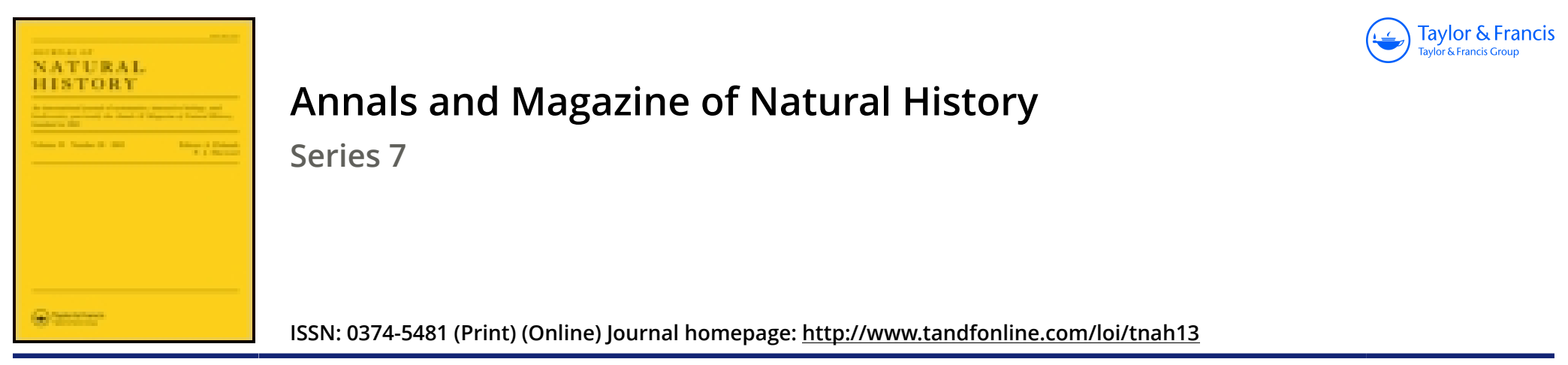

\title{
XXXVIII._-On three new races of Tragulus kanchil, Raffles, with remarks on the genus
}

\section{J. Lewis Bonhote M.A.}

To cite this article: J. Lewis Bonhote M.A. (1903) XXXVIII._On three new races of Tragulus kanchil, Raffles, with remarks on the genus, Annals and Magazine of Natural History, 11:63, 291-296, DOI: 10.1080/00222930308678769

To link to this article: http://dx.doi.org/10.1080/00222930308678769

Published online: 28 Sep 2009.

Submit your article to this journal $₫$

Џ Article views: 2

Q View related articles $\square$

Citing articles: 1 View citing articles ๘ 
to alveolus of $p^{2} 71$; palate length 110 ; length of upper tooth-row 56.

Hab. Fanti.

Type. Adult male. B.M. no. 97. 1.5.2. Collected by Aubinn, acquired by Sir Victor Brooke, and presented by the latter's son, Sir Douglas Brooke.

This distinct species, the mainland representative of C. Ogilbyi, is readily distinguishable from that animal by the reversed hairs of the nape, the much broader dorsal streak, which does not run on to the tail, the light-coloured feet, and by the less swollen frontal region of its skull.

It is still possible that $C$. Ogilby $i$ may occur on the mainland, but these Fanti specimens are certainly not referable to it.

XXXVIII._On Three new Races of Tragulus kanchil, Raffles, with Remarks on the Genus. By J. Lewis BONHOTE, M.A.

A FEW months ago Messrs. Stone and Rehn published a paper on some mammals from Sumatra , and included in it a revision of the genus Tragulus.

With their findings as a whole I quite agree, and, having: had occasion lately to look up the genus, I find that we have in the British Museum three apparently undescribed forms of the smaller Chevrotain from Borneo, Bunguran Island, and Cochin China, which I propose to describe.

Before doing so, however, it may perhaps be as well to make a few remarks on the whole genus.

Many naturalists cavil greatly at the mass of names that is slowly but surely rising round each group, which they would call a single species, and thereby refuse to recognize geographical forms. Now these races, which arise from their geographical position, represent no doubt the initial differentiations of new species, and, far from being ignored, should be most closely studied. The easiest and simplest method of doing so is to describe them and recognize them by means of trinomials.

I cannot agree with those who, while using trinomials for continental races, refuse to allow them for insular races, on

* Proc. Acad. Nat. Sci. Philad. p. 127 (1902). 
the plea that, as intermediate forms do not exist, they must be regarded as separate species.

The present genus offers a very good example of the confusion that may arise from adhering to binomials for insular races.

Messrs. Stone and Rehn, omitting all Mr. Miller's late species, give a list, excluding synonyms, of eight species, with nothing to show that some are much more closely related than others.

If Mr. Miller's recent forms be taken into account, we find the number of species doubled, and this mass of names, if not connected in groups as indicated by trinomials, can only lead to confusion rather than to a clearer understanding of the genus.

If the subject be carefully studied, we find that there are only four, or, at the most, five species, viz., T. meminna, T. Stanleyanus, T. javanicus (Osbeck, nec Gm.) (the T. napu of authors), T. kanchit, Raffles (the T. javanicus (Gm.) of authors), and possibly $T$. fulviventer. Of the first two species but little is known, while T. javanicus and $T$. lanchil are represented by a slightly different form on almost all the islands of their range.

With regard to T. fulviventer, externally it much resembles some of the forms of $T$. kanchil, but there are certain cranial differences which would seem to point to its being a distinct species. If its true habitat be Malacca, as is stated by Gray, it must, of course, be regarded as distinct; but from its general appearance I suspect its real home is to the east either on the mainland or one of the islands, in which case it can only be considered a race of $T$. kanchil.

The differences between $T$. leanchil from Sumatra and T. kanchil pelandoc from Java, as stated in the paper quoted above, do not appear to hold good in all cases. In two specimens from Java which I have examined one resembles pelandoc on the throat and kanchil on the nape, while the other has the nape of pelandoc and throat of kanchil, so that further evidence is required as to the distinctions between these forms.

Messrs. Stone and Rehn appear to have overlooked a species described by Gray under the name of Tragulus affinis (P. Z. S. 1861, p. 138). Gray, in his description, states that it is a pale-coloured variety much resembling those from Cochin China, and that it is supposed to have come from Singapore. Under these circumstances Mr. Miller was quite justified in describing the form found in the Malay Peniusula as new. 
Gray's type, however, is in the British Museum, and a comparison with specimens from the Peninsula shows that it agrees with them exactly, but does not agree with the specimen from Cochin China described in this paper.

Under these circumstances, therefore, Mr. Miller's name of ravus has to give place to Gray's name, and the small chevrotain from the Peninsula should be known as T. kanchil affnis.

The following belong to apparently undescribed races of T. kanchil:-

\section{Tragulus kanchil Pierrei, subsp. n.}

Size as in Trag. kanchil affinis, Gray.

General colour throughout very uniform and of a dull yellowish brown, slightly darker on the back, the general tone being between "wood-brown and tawny olive" * shading in the darker portions to "mummy-brown" *. The underpart of the chin and throat (except for the usual markings), the chest, and the inner sides of all four limbs are white. The belly is pale ochreous and the markings on the throat, which form a complete triangle, brownish clay.

The skull does not appreciably differ from that of $T . k$. affinis of the Peninsula, except in being a tritle more stoutly built. The nasals are narrower and the bullæ somewhat broader, $i$. e projecting farther downwards. The basioccipital is more constricted and its downward processes much more marked.

Dimensions (from skin):-Head and body 420 millim.; tail 57 ; tarsus 81 .

Skull.-Greatest length 89 millim.; basal length 76 ; palatal length 57 ; length of nasals 25 ; maxillary tooth-row 32 ; zygomatic breadth 42 ; length of bullæ 17 ; greatest breadth of bullæ 7.5.

Hab. Bien Hoa, Lower Cochin China.

Type. B.M. 78. 6. 17. 18. Collected by M. Pierre, February 1877.

The very brownish colour of this animal and absence of any black serve to distinguish it from all other forms. It is most nearly related to T. k. affinis, Gray.

\section{Tragulus kanchil Hosei, subsp. n.}

A brightly coloured Tragulus slightly larger than $T$. $k$. affinis.

* 'These are the names given in Ridgway's ' Nomen. of Colours.' Ann. \& Mag. N. Hist. Ser. 7. Vol. xi. 
General colour on the back black, strongly grizzled with rufous, which latter colour predominates, but is slightly yellower in tint on the sides. Head and face as the back, lighter on the cheeks. Nape-stripe very well defined and nearly pure black. Sides of neck and fore feet rufous, hind feet similar in colour to the back. Well-defined orange markings start from inside the fore legs and run backwards and inwards to join in the middle line, thence passing backwards along the median line to the vent, where it widens out into a broad irregular transverse band. There is a further narrow line of this colour bordering the colour of the upper parts and bordering both sides of the white on the inner side of the thighs. The median ventral stripe is also carried forward to meet the transverse stripe on the neck. The markings on the neck are of the usual shape and are orange-rufous thickly grizzled with black. The remainder of the underparts are pure white. The tail, which is longer than in T.k. affinis, is similar in colour to the rest of the body, viz., grizzled rufous above and white below.

The skull is similar but larger than that of $T$. k. affinis, the most noticeable point of difference being in the bullæ, which are very much swollen and rounded and nearly twice as large; as a result of this the constriction of the anterior portion of the basioccipital, noticed when dealing with the last species, has gone a stage further and become still more constricted, so that the whole bone is rather wedge-shaped, with the sharp edge downwards, leaving a fairly deep groove on either side between the wedge and the bullæ. Another point of difference is in the anterior margin of the præmaxillæ, which bends abruptly downwards from the anterior end of the nasals, whereas in T. k. affinis and T. k. Pierrei it goes down in a more gradual slope.

Dimensions (of type) from dried skin:-Head and body 472 millim.; tail 75 ; hind tarsus 98.

Skull.-Greatest length 98 millim.; basal length 86 ; palate length 62 ; length of vasals 29 ; zygomatic breadth 42 ; length of maxillary tooth-row 32 ; length of bullæ 20; greatest breadth of bullæ 10 .

Hab. Baram River, Sarawak.

Type. Adult female. B.M. 0. 8. 4. 10. Collected and presented by Mr. C. Hose.

This handsome race is most nearly allied to T. fulviventer, from which it differs chiefly in its larger size and rather paler coloration. T. fulviventer has, in addition, a clear orange transverse band on the throat connecting the apex of the triangle with the colour of the upper parts on either side, 
while it lacks the irregular transverse band across the vent. I am doubtful if there is any specific value attaching to these markings of the underparts, but perhaps it is as well that they should be noted.

If we turn to the skull we find that $T$. fulviventer is intermediate in form between $T$. affinis and the present subspecies. It is intermediate in size, intermediate in the constriction of the basioccipital, and intermediate in the amount of swelling undergone by the bullæ. The præmaxillæ, however, are of the T. Hosei type. The maxillary tooth-row is precisely the same length in all three forms, and in the case of $T$. affinis and $T$. Itose $i$ the teeth are practically alike, but in $T$. fulviventer there is a curious change, which I take to be merely an individual variation. The second molar in the upper jaw on either side is considerably broader, measuring 7 millim., as against 5 millim. in $T$. Hosei, and the last molar is reduced to a single conical cusp.

\section{Tragulus kanchil Everetti, subsp. n.}

Appearance similar to T.k. Hosei, but deeper in colour and rather smaller.

General colour like T. $k$. Hosei, except that the red on the flanks is much deeper, being rufous ("ochraceous rufous," Ridgw.) instead of deep buff (" orange-rufous," Ridgw.).

Underparts pure white, with the exception of one long median ventral stripe, broad and of an orange colour over the belly, but narrow and grizzled anteriorly. There is a very faint trace of the transverse abdominal band, and a patch of orange on the thighs narrows down the white to a thin stripe.

The skull, which is slightly smaller than that of $T . k$. Hosei, may be at once distinguished by its large teeth and small bullæ. 'The præmaxillæ, instead of sloping gradually downwards after leaving the nasals, as in $T$. affinis, or narrowing abruptly, as in T. Hosei, continue forwards at their original breadth for some 3 millim., and then suddenly turn down abruptly. In other respects the skull does not differ from that of $T$. $k$. Hosei.

Dimensions (of type) from dried skin:-Head and body 450 millim.; tail 73 ; hind tarsus 89.

Skull.-Basal length 83 millim.; palatal length 60; length of nasals 29 ; length of maxillary tooth-row 35 ; zygomatic breadth 44 ; length of bullæ 16 ; breadth of bullæ 7 .

$H a b$. Bunguran Island, Natunas.

Type. Adult female. B.M. 94. 9. 28. 21. Collected on the 1st October, 1893, by Mr. A. H. Everett. 
Externally the bright colour of this race is sufficient to distinguish it at a glance. As regards cranial characters, the large teeth and small bullæ are such conspicuous and readily seen features as to enable it to be very easily identified, while at the same time forming characters which leave no doubt in my mind that the island race is a good and well-marked form.

I append a list of the hitherto described species, with references to the original descriptions and the localities in which they were obtained :-

1. Tragulus meminna, Erxl. Syst. Regn. An. p. 322 (1777). -Ceylon and S. India.

2. Tragulus Stanleyanus, Gray, P. Z. S. 1836, p. 65.-Loc. Unknown.

3. Tragulus javanicus (Osbeck, nec Gm.) (T. napu of authors).

Cervus javanicus, Osbeck, Reise nach Ostindien und China, p. 357 (1765).-Jara.

Tragulus javanicus naps (F. Cuv.), Mist. Nat. Mamm. pl. ccexxix. (1822).--Sumatra.

T. j. nigricans, Thos. Ann. \& Mag. Nat. Hist. ser. 6, vol. ix. p. $2 \pi 4^{2}$ (1892).-Philippines.

T. j. rufulus, Miller, Proc. Wash. Acad. Sci. ii. p. 227 (1900).-Tioman Island.

T. j. canescens, Niller, Proc. Biol. Soc. Wash. xiii. p. 185 (1900).Tury, L. Siam.

T.j. umbrinus, Miller, Proc. Biol. Soc. Wash. xiii. p. 191 (1900).Pulo Lankawi.

T. j. bunguranensis, Miller, Proc. Wash. Acad. Sci. iii. p. 113 (1901).Bunguran Island.

T. j. pretiosus, Miller, Proc. Acad. Nat. Sci. Philad. p. 144 (1902).Linga Island.

T.j. borneanus, Miller, Proc. Biol. Soc. Wash, xv. p. 174 (1902).British North Borneo.

4. Tragulus kanchil, Raffles (T. javanicus (Gm.) of authors).

Tragulus kanchil, Rafles, Trins. Linn. Soc. xiii. p. 26:2 (1822).Sumatra.

T. k. pelandoc, Ham. Smith, Griff. Auim. Kingd. iv. p. 66 (1827).Java.

T. k. fulviventer, Gray, P. Z. S. 1836, p. 65.-Malay Peninsula?

T. k. affinis, Gray, P.Z. S. 1861, p. 138.-Singapore.

T. K. pallidus, Miller, Proc. Wash. Acad. Sci. iii. p. 116 (1901).Pulo Laut.

T. k. Pierrei, mihi.--Lower Cochin China.

T. k. Hosei, mihi.-Baram River, Sarawak.

T, k. Everetti, mihi-Bunguran Island. 